\author{
A Final Manuscript \\ for \\ Journal of Professional Issues in Engineering Education and Practice, \\ ASCE \\ (Legal Affair Section)

\section{"Exploring the Influence of Contract Governance on Construction Dispute Negotiation"}

(The readers of the paper shall include both researchers and practitioners.)

(Manuscript \#: EI/23746)

by

Sai On Cheung*, Wei Kei Wong, Tak Wing Yiu and Tim Wai Kwok Construction Dispute Resolution Research Unit

Department of Building and Construction

City University of Hong Kong

*Corresponding Author

Sai On Cheung*

Construction Dispute Resolution Research Unit

Department of Building and Construction

City University of Hong Kong

83 Tat Chee Avenue

Hong Kong

Tel: $852-27887603$

Fax: 852-27887612

Email: bcsoc@cityu.edu.hk 
$17^{\text {th }}$ November 2007

\title{
Exploring the Influence of Contract Governance on Construction Dispute Negotiation
}

\author{
Sai On Cheung, Wei Kei Wong, Tak Wing Yiu and Tim Wai Kwok \\ Construction Dispute Resolution Research Unit \\ Department of Building and Construction \\ City University of Hong Kong
}

Abstract

The obligations and rights of the contracting parties are typically set out in the conditions of contract. The attempt to have a 'water-proof' contract that caters for all eventualities has turned contracts into management manuals with detailed contractual procedures to deal with, inter alia, performance, changes, payment, approval and dispute resolution. Contract disputes therefore have to be negotiated within the ambits of the contracts. This study revisits the assumption of free negotiation that underpins most conventional negotiation studies, i.e. negotiation is free with rational negotiators who can walk away from the negotiating table at will. Constraints imposed by a contract are collectively described as contract governance. With taxonomies developed through Principal Component Factor Analyses (PCFA) for contract governance (CG) and negotiating behaviors (NH), the influence of $\mathrm{CG}$ and $\mathrm{NH}$ is explored by a Pearson Correlation Analysis (PCA). In general, it was found that dominating and obliging behaviors are mostly influenced by CG while compromising behavior is least influenced. It was further found that procedural requirements influence all types of negotiators under the Rahim Organizational Conflict Inventory except integrators. This suggests that if negotiators are having concern for both 
themselves as well as their counterparts, amicable settlement is possible notwithstanding the complex procedural requirements.

\section{Introduction}

Construction activities are regulated by contracts that define obligations and rights of the contracting parties. As project complexities increase, contracts have evolved and now function more like management manuals detailing the contractual procedures to deal with, inter alia, the performance, changes, payment, approval and dispute resolution. These details can be solely procedural, but in many instances, are having time and cost implications. These constraints are collectively identified as contract governance (CG) for the study reported in this paper. Negotiation studies typically assume free negotiation (Zack 1994; Loosemore 1999; Ren et al. 2002; Cheeks 2003). This study aims to revisit this assumption and explore the influence of contract governance on construction dispute negotiation.

\section{Influence of Contract Governance on Negotiating Behaviors}

Undoubtedly, negotiation behaviors are affected by many factor groups. The one that has mostly been reported is personality (Allred 2000; Baxter 1972; Lytle et al. 1999; Mintu-Wimsatt and Calantone 1996; Shell 2001; Terhune 1970). This is particularly relevant in negotiations among individuals. However, when negotiators are representing their organizations, factors such as organizational culture and project objectives shall have an 
influence on the negotiation plan, thus the behaviour of the negotiators. In addition, Evans and Beltramini (1987) advocate that there is a need to understand the negotiation antecedents and introduce the concept of pre-transaction conditions as a factor affecting negotiation orientation. In essence, this refers to the contextual elements under which a negotiation is conducted. In construction dispute negotiation, this will be the contract governance. In this study, contract governance refers to the constraints/conditions that a construction dispute negotiation is subject to. For example, the validities of a submission and the associated quantum have to be evaluated within the ambit of the contract. The negotiating parties of a construction dispute may not easily leave the negotiation table notwithstanding that an impasse has been reached nor the prospect of having the demand met is slim (Ren et al. 2002). This can be attributed to a number of reasons. Firstly, the initial negotiation inevitably has to be conducted within the contract framework. Secondly, in most construction contracts, if negotiation fails, the dispute would need to be resolved by one of the formal proceedings such as arbitration and litigation. The implication of this kind of arrangement can be negative or positive. On the up-side, if both parties wish to avoid the costly process, there is a strong incentive for the parties to direct effort and energy for a negotiated settlement. However if one party takes an opportunistic move and presses for concession by inducing exorbitant cost through delaying tactics, a negotiated settlement shall then be very distant. This is because the reaction of the other party is likely to be offensive. From another perspective, Loosemore (1999) investigated tactics used in 
bargaining construction disputes. He distinguishes bargaining from negotiation because of the constraints faced by the disputants. Bargaining involves a struggle between adversaries who attempt to move, step-wise, towards an agreement over resources redistributions which are in their own favor. Construction negotiators belong to and represent the interests of distinct profit-making organizations. In this situation, the negotiation plan of the disputants take account of the objectives of their organizations as well as the boundaries set by the contract provisions. To this end, Cheung and Yiu (2006) advocate that construction disputes have of three basic components: contract provisions, triggering events and conflicts. This conceptualization highlights firstly the importance of contract provisions in identifying construction disputes. More specifically, the triggering event component of a construction dispute refers to the happenings that may give rise to a disputious situation. Table 1 gives the dispute triggering events identified by Cheung and Yiu (2006).

$<$ Table 1 here >

Based on the four sub-groups of triggering events and from a procedural perspective as shown in Table 1, the list of contract governance used in this study are summarized in Table 2.

$<$ Table 2 here >

\section{The Study}

Figure 1 presents the research framework of this study. Three stages of work are involved.

The research tasks, methodologies and deliverables are summarized in Table 3. 
$<$ Figure 1 here >

$<$ Table 3 here >

Two key questions were first addressed in the first two stages of the study:

1. What are the typical behaviors in construction dispute negotiation?

2. What constitutes contract governance?

Stage Three of the study aims to explore the influence of contract governance on negotiating behaviours.

Questionnaire Design and Data Collection

A questionnaire survey was used to collect data on negotiating behaviors and contract governance. Case specific data is needed to develop the taxonomies, the respondents were asked to refer to one of their most recent negotiation cases in answering the questions listed in the questionnaire. The questionnaire has three sections. Respondents were requested to provide their background and the particulars of their negotiated cases such as project nature, contract sum and parties involved in the first section. The other two sections address negotiating behaviors and contract governance respectively. For the measurement of negotiating behaviours, studies by Kilmann and Thomas (1977), Blake and Mouton (1964, 1970) and Thamhain and Wilemon $(1975,1987)$ have been reported in the field of management. Among these, the framework of Blake and Mouton $(1964,1970)$ that has been widely used to identify negotiation behaviors (Hammock et al. 1990, Gross et al. 2000, 
Chakrabarty et al. 2002). It was used in this study. There are five negotiating behaviors in this model: forcing, withdrawing, smoothing, compromising, and problem solving. Based on this framework, Rahim and Bonoma (1979) and Rahim (1983) aligned negotiating behaviors into two basic dimensions: concern for self and concern for others. Concern for self represents the degree to which a person attempts to satisfy his or her own concerns, while concern for others represents the degree to which a person wants to satisfy the concerns of others. Accordingly, a negotiating behaviors inventory called 'Rahim Organizational Conflict Inventory II (ROCI-II)' (Rahim, 1983) was developed. This inventory has been widely applied in conflict management studies (Friedman et al. 2000; Loosemore 1999; Chakrabarty et al. 2002; Elsayed-Ekhouly and Buda, 1996). Rahim (1983) further proposed integrating, obliging, avoiding, dominating and compromising as the five main negotiating behaviors. The structure has been validated through testing with a large executive sample. It has also been further developed in different forms for subjects including supervisors, subordinates, and peers (Womack 1988). In this connection, ROCI-II is selected as the inventory to measure negotiating bahaviors for this study. The 28 questions included in ROCI-II were modified to suit the construction context. The modified questions are listed in Table 4. As for contract governance, the questions were developed from the variables listed in Table 2.

$<$ Table 4 here > 
The respondents were asked to rate the degree of agreement of the statements representing their negotiation behavior during the dispute negotiation on a Likert scale of 1 (strongly disagree) to 7 (strongly agree). Likewise, the constraints/conditions of the particular case (i.e. the contract governance) were rated in a Likert scale of 1 (not significant) to 7 (most significant).

A total of 252 questionnaires were sent to a group of respondents identified from the builder directory and construction related professional institutes in Hong Kong. 80 of them returned the questionnaire, representing a response rate of $31.75 \%$. The profiles of the respondents in terms of professional qualifications and working experience are given in Figure 2.

$<$ Figure 2 here >

Figure 3 summarizes the forms of contract involved in the negotiated cases of the respondents. $35 \%$ of the negotiated cases were negotiated within the framework of the Agreement and Schedule of Conditions of Building Contract (35\%). Another 35\% of the cases were related to projects using the Government of the Hong Kong Special Administrative Region General Conditions of Contract (HKSARGCC) for Building Works. The other forms of contract used included Government of the Hong Kong Special Administrative Region General Conditions of Contract for Civil Engineering Works (11\%) and for Electrical and Mechanical Works (4\%). All these forms of contract are commonly used in Hong Kong. 
$<$ Figure 3 here >

\section{Taxonomies of Negotiating Behaviors}

Taxonomy is a system by which categories are related to one another by means of class inclusion (Rosch 1988). The use of Principal Component Factor Analysis (PCFA) can explore the structure of the data to define a set of common underlying constructs, known as factors. Accordingly, separate dimensions of the structure can be identified. Interpretation of variables can be accomplished by summarizing the data according to the constructs (Hair et al. 1995). In this connection, PCFA can be used to develop taxonomies of negotiating behaviors. The acceptance of the results is subject to meeting the statistical fitness criteria of Kaiser-Meyer-Olkin (KMO) and Bartlett's Test (BT), both measure the sample adequacy for factor analysis (Hair et al. 1995). The KMO value ranges from 0 to 1 and the threshold for acceptance is 0.50 and above (Holt 1997). The significance value of BT shall less than 0.05. In this study, the PCFA results satisfied these statistical fitness criteria. The KMO value of the PCFA was 0.650 , while the significance of the BT was 0.00 . The final factor matrix was given in Table 4.

The PCFA gave a five factor solution, suggesting five taxonomies of negotiating behaviors. The items included for each factor are close to the classifications by Rahim (1983). In brief a person with integrating style would have high concern for self and high concern for other. $\mathrm{He} / \mathrm{she}$ is willing to generate solution that satisfies his/her concerns as well as those of the 
other. While the compromising style reflects intermediate levels of concern for self and other; whereby mid-ground solution through mutual concession is typical. The dominating style results from a low concern for other with high concern for self. The avoiding style involves low concern for both self and other. Negotiators with this style tend to withdraw from the conflict solution and/or sidestepping the negotiating issues. With high concern for other and low concern for self, negotiators with the obliging style tend to give in to the demands and wishes of the other party.

\section{The Taxonomies of Contract Governance}

The taxonomies of contract governance were also developed by performing PCFA with the same procedures as described. The sufficiency of the data set for PCFA was also confirmed by a KMO value of 0.566 and a low significance in the BT. The final factor matrix was given in Table 5.

$<$ Table 5 here $>$

The result obtained in the factor analysis suggested four taxonomies of contract governance as follows: -

Factor 1: Procedural requirement;

Factor 2: Burden of proof;

Factor 3: Ambiguous provisions, and

Factor 4: Condition precedent. 
The factor names are generic descriptions of the contract governance variables included.

Table 6 also gives the mean scores and standard deviations of each of the factor groups. The high mean score suggested that most of the respondents agreed that condition precedent had been one of the major constraints/conditions during negotiation. This finding reflects the fact that negotiating parties must comply with the specified procedure if he/she is to avail him/herself to other contractual entitlements. Otherwise, he/she is considered deem to have waived his/her contractual rights. In construction, such remedies are typically time extension and monetary compensation (Rawling 2001). In this connection, compliance of the condition precedent requirement shall be first established.

\section{Stage Three: Influence of Contract Governance on Negotiating Behaviors}

Taxonomies of the two dimensions: negotiating behaviors and contract governance had been developed in Stages One and Two respectively. With these, this stage of the study seeks to explore the influence of $\mathrm{CG}$ on negotiating behaviors. For this purpose, a Pearson Correlation Analysis (PCA) was conducted. The strength and direction (positive or negative) of this relationship is assessed by Pearson's correlation coefficient $(\rho)$ that may take any value between -1 and 1. A positive correlation means that as one variable increases, the other likewise increases. A negative correlation means that as one variable increases, the 
other decreases (Billingsley and Huntsberger 1990).

Based on the taxonomies of negotiating behaviors and contract governance as listed in Tables 2 and 4 respectively, five factor scales of negotiating behaviors and four factor scales of contract governance can be computed. These scales are the composite measure created for each observation on each factor extracted in the factor analyses (Hair et al. 1995), and were used for the Pearson's Correlation Analysis (PCA). Cohen (1988) offered a 'rule of thumb' type of interpretation of Pearson correlation coefficient. Based on the magnitudes of correlation coefficient, the strengths of correlation can be roughly divided into three categories: small, medium and large (Table 7 refers). The results of the PCA were summarized in Table 7. A total of 20 PCAs (devised from the combination of four and five factor scales of contract governance and negotiating behaviors respectively) were performed. As shown in Table 7, among these 20 Pearson correlation coefficients $(\rho), 11$ of them are significant.

\section{$<$ Table 7 here >}

These results were used to track the existence of relationship between contract governance and negotiating behaviors. For example, as shown in Table 7, a positive relationship is found between integrating behavior and contract governance of Burden of Proof. This suggests that a negotiator with integrating behavior is likely to be constrained by the contract governance of Burden of Proof. In general, the degree of influence of contract governance on negotiating 
behaviors is considered by the number of contract governance that shows significant correlation with the behavior.

From Table 7, it can also be seen that the extent of influence by contract governance rises across the five negotiating behaviors. Dominating behaviors are significantly correlated with three (out of the four) types of contract governance: Procedural Requirement $(\rho=.257$ at $p<.05)$, Burden of Proof $(\rho=.258$ at $p<.05)$ and Ambiguous Provisions $(\rho=.229$ at $p<.05)$. While the contract governance of Procedural Requirement $(\rho=.326$ at $p<.00)$, Ambiguous Provisions $(\rho=.270$ at $p<.02)$ and Condition Precedent $(\rho=.229$ at $p<.04)$ are significantly correlated to the obliging behaviors. Furthermore, two (out of four) types of contract governance are correlated to integrating and avoiding behaviors: The contract governance of Burden of Proof $(\rho=.317$ at $p<.00)$ and Condition Precedent $(\rho=.412$ at $p<.00)$ are significantly correlated with integrating behaviors, and the contract governance of Procedural Requirement $(\rho=.300$ at $p<.01)$ and Ambiguous Provisions $(\rho=.490$ at $p<.00)$ are significantly correlated to avoiding behaviors. In this respect, these two negotiating behaviors are considered to be influenced by the contract. Finally, out of the four types of contract governance, only Procedural Requirement $(\rho=.383$ at $p<.00)$ is significantly correlated to compromising negotiating behaviors. In other words, contract governance has little influence on the compromising style. 
Aligning the PCA results with Rahim's (1983) framework, some interesting observations can be noted. Negotiating behaviors with low concern for self and high concern for other or high concern for self and low concern for other, i.e. dominating or obliging, are mostly influenced by contract governance. According to Rahim (1983, 2002), negotiators with a dominating style are characterized with a win-lose orientation or a forcing behavior to win one's position, they would often ignore the needs and expectations of other parties. Negotiators with an obliging style, on the other hand, tend to neglect their own concern in order to satisfy the concern of other parties, and are characterized by playing down differences and emphasizing commonalities. In the light of these characteristics, when a negotiator with dominating style is subject to contract governance during negotiation, the degree of concern for self would intensify. This was supported by the positive correlations between dominating negotiating behaviors and contract governance (Table 7 refers). Likewise, an obliging negotiator who has a high concern for other would give due regard to contract provisions. Nonetheless, negotiators who have high concern for self as well as the other are found to be less influenced by contract governance. This category of negotiators gives priority to cooperation, collaboration, solution-orientation, problem solving and attempts to reach an effective solution acceptable to both parties. They are therefore relatively more flexible and adaptive. They are more willing not to insist on the contractual requirements, thus enhancing the possibility of deriving creative solutions. Lastly, it is not surprising to find that a compromising negotiator is least influenced by contract governance. 
This is due to the fact that such negotiators would give up more easily than the dominating negotiators, but less so than the obliging negotiators. The compromising negotiators address an issue more directly than the avoiding negotiators, but do not explore it in depth as much as the integrating negotiators (Rahim 1983, 2002). In this connection, the compromising negotiators would agree to a 'split the difference' type of settlement and they would be least influenced by contract governance.

It can be noted from Table 8 that the procedural requirement shows significant correlation with four of the five negotiating behaviors under the Rahim conflict handling style framework (Rahim 1983).

In fact, it is common practice nowadays to detail procedures to deal with eventualities contemplated by the contract drafters. These procedures are typically technical in nature and can be instrumental in blocking claim submissions, at least procedurally. Integrators under the Rahim's framework show no significant correlation with procedural requirement and this preserves the conventional wisdom that if both negotiators show concern for their negotiating counterpart, construction dispute negotiation can be collaborative despite how the acrimonious the terms of contract are.

\section{Conclusion}

Conventional negotiation studies assume free negotiation whereby negotiators are rational and can leave the negotiation table at will. However this is far from the real life situation in 
the case of construction dispute negotiation. It is because most construction projects are monitored by very sophisticatedly prepared conditions of contract. The constraints are collectively described as contract governance. This study revisits the assumption of free negotiation and examines the influence of contract governance on construction dispute negotiation behavior. Data was collected through a questionnaire survey. Accordingly, taxonomies for contract governance and negotiation behavior were developed. The influence of contract governance on negotiating behaviors was explored through a Pearson Correlation Analysis. As far as the range of contract governance is concerned, it was found that negotiators of the dominating and obliging styles are more readily influenced by contract governance while compromising negotiators are least influenced. It was also found that contract procedural requirements influence all types of negotiators under the Rahim's conflict handling style framework (Rahim 1983) except integrators. While the use of 'water-proof' contract has become the norm in construction contracting, the sophistication in procedural requirement stifles rational negotiation as suggested in conventional negotiation theory. Moreover, 'integrating' negotiators who give due respect to other's concern would have better chance to craft out mutually accept settlement despite the acrimonious terms of contract.

\section{Acknowledgement}

The work described in this paper was fully supported by a grant from the City University of 
Hong Kong (Project No: 7001597). The authors are thankful for the constructive comments of the reviewers.

\section{References}

1. Allred, K. (2000). "Distinguishing best and strategic practices: a framework for managing dilemma between creating and claiming value", Negotiation Journal October: 387- 397.

2. Bazerman, M.H. and Lewicki, R.J. eds (1983). "Negotiating in organizations". Newbury Park, CA:Sage.

3. Blake, R.R. and Mouton, J. S. (1964). "The Managerial Grid”, Houston: Gulf.

4. Blake, R.R. and Mouton, J.S. (1970). "The fifth achievement". Journal of Applied Behavioral Science, 6, 413-436.

5. Carnevale, P. and Pruitt, D. (1992) "Negotiation and Mediation" in Annual Review of Psychology Rosenzweig M. and Porter L. (Eds) 43, 531-582.

6. Chakrabarty, S., Brown, G. and Gilbert, A.H. JR. (2002). "Evaluation of Rahim's Organizational Conflict Inventory - II as a Measure of Conflict Handling Styles in a Sample of Indian Salespersons", Psychological Report, Vol. 90, pp.549-567.

7. Cheeks, J.R. (2003) "Multistep dispute resolution in design and construction industry", Journal of Professional Issues in Engineering Education and Practice, 129(2), 84-91.

8. Cheung, S.O., Tam, C.M., Ndekugri, I. and Harris, F.C. (2000) "Factors affecting clients' project dispute resolution satisfaction in Hong Kong". Construction 
Management and Economics, 18, 281-294.

9. Cheung, S.O., Yiu, T. W. and Suen, H. (2004) "CoNegO: Construction Negotiation Online", The Journal of Construction Engineering and Management, ASCE, 130(6), 844-852.

10. Cheung, S.O. and Yiu, T.W. (2006) “Are construction disputes inevitable?" IEEE Transactions on Engineering Management, 53(3), 456-470.

11. Cheung, S.O. Yiu, T.W. and Yeung, S.F. (2006). "A study of styles and outcomes in construction dispute negotiation". Journal of Construction Engineering and Management, 132(8), 805-814.

12. Cohen, J. (1988). Statistical power analysis for the behavioral sciences (2nd ed.) Hillsdale, NJ: Lawrence Erlbaum Associates.

13. Druckman, D. eds (1977). “Negotiations: Social Psychological Perspectives". Beverly Hills, CA:Sage.

14. Druckman, D., Harris, R. and Ramberg, B. (2002). “Computer-assisted International Negotiation: A Tool for Research and Pratice", Group Decision and Negotiation, 11: 231-256.

15. Elsayed-Ekhouly, S.M. and Buda, R. (1996). "Organizational Conflict: A Comparative Analysis of Conflict Styles Across Cultures", The International Journal of Conflict Management, pp.71-81.

16. Friedman, R.A., Currall, S.C. and Tsai, J.C. (2000). "What Goes Around Comes 
Around: the Impact of Personal Conflict Style on Work Conflict and Stress", The international Journal of Conflict Management, 11(1), 32-55.

17. Gross, M.A. and Guerrero, L.K. (2000). "Managing Conflict Appropriately and Effectively: an Application of the Competence Model to Rahim's Organizational Conflict Styles", The International Journal of Conflict Management, 11(3), 200-226.

18. Hair, A, Tatham, R.L. and Black, W.C. (1995). Multivariate Data Analysis, $5^{\text {th }}$ Ed., Prentice Hall, Englewood Cliffs, NJ; 1995.

19. Hammock, G.S., Richardson, D.R., Pilkington, C.J. and Utley, M. (1990). "Measurement of Conflict in Social Relationships". Personality and Individual Differences, 11(6), 577-583.

20. Hills, M.J. (1995). “Building Contract Procedures in Hong Kong”, $2^{\text {nd }}$ Edition, Hong Kong : Longman.

21. Holsapple, C., Lai, H. and Whinston, A. (1998). "A Formal Basis for Negotiation Support System", Group Decision and Negotiation, 7, 203-227.

22. Holt, G.D. (1997). "Construction research questionnaire and attitude measurement: relative index or mean". Journal of Construction Procurement, 3(2), 88-94.

23. Kagel, J. and Roth, A.E. (eds) (1991). "Handbook of experimental Economics". Princeton NJ: Princeton University Press.

24. Kremenyuk, V. (ed.) (1991). "International Negotiation: Analysis, Approaches, Issues". San Francisco: Jossey-Bass. 
25. Lax, D.A. and Sebenius, J.K. (1986) "The Manager as negotiator: bargaining for cooperation and competitive gain". New York: Free Press.

26. Lewicki, R.J. and Litterer, J. (1985). "Negotiations". Homewood, IL: Richard D. Irwin.

27. Lewicki, R.J., Sheppard, B.H. and Bazerman, M.H. eds (1986). "Research on Negotiation in Organizations", vol. 1 Greenwich, CT: JAI Press.

28. Li, H. (1996) "Case-based reasoning for intelligent support of construction negotiation". Information and Management, 30, 231-238.

29. Loosemore, M. (1999). "Bargaining tactics in construction disputes", Construction management and Economics, Vol. 17: 177-188.

30. Lytle, A., Brett, J. and Shapiro, D. (1999), “The Strategic Use of Interests, rights, and power to resolve disputes", Negotiation Journal, January 31-51.

31. Omoto, T., Kobayashi, K. and Onishi, M. (2002). "Bargaining Model of Construction Dispute Resolution". IEEE International Conference on Systems, Man and Cybernetics, 7, 6-9.

32. Putman, L.L. and Roloff, M.E. (1991). “Communication Perspectives on Negotiation”. Newbury Park, CA: Sage.

33. Rahim, M.A. (1983). "Rahim Organizational Conflict Inventory-II", Palo Alto, CA: Consulting Psychologists Press.

34. Rahim, M.A. (2002). "Toward a Theory of Managing Organizational Conflict", The international Journal of Conflict Management, 13(3), 206-235.

35. Rahim, M.A. and Bonoma, T.V. (1979). "Managing organizational conflict: A model for 
diagnosis and intervention". Psychological Reports, 44, 1323-1344.

36. Rawling, B.E. (2001). “Conditions Precedent”, HKIS Newsletter, 10(6).

37. Ren, Z., Anumba, C.J. and Ugwu, O.O. (2002). "Negotiation in a multi-agent system for construction claims negotiation", Applied Artificial Intelligence 16: 359-394.

38. Rubin, J.Z. and Brown, B. (1975). "The Social Psychology of Bargaining and Negotiations". New York: Academic.

39. Shell, G.R. (2001). "Bargaining styles and Negotiation: The Thomas-Kilmann Conflict Mode Instrument in Negotiation Training”, Negotiation Journal, April 155-174.

40. Steven, C.M. (1963). "Strategy and Collective Bargaining Negotiation". New York: MaGraw Hill.

41. Walton, R. and McKersie R. (1965). “A Behavioral theory of labor negotiation: An analysis of a social interaction system". New York: McGraw Hill.

42. Womack, D.F. (1988). “A Review of Conflict Instruments in Organizational Settings”, Management Communication Quarterly, 1(3), 437-445.

43. Zack, J.G. (1994). "The negotiation of settlements - A team sport”, Cost Engineering, 36(8), 40-30.

44. Kilmann, R.H. and K.W. Thomas. (1977). Developing a forced-choice measure of conflict-handling behavior: The 'Mode' Instrument. Educational and Psychological Measurement 37: 309-325.

45. Thamhain, H.J., Wilemon, D.L., (1975). Conflict management in project life cycles. Sloan Management Review 17(3), 31-50. 
46. Thamhain, H.J. and Wilemon, D.L (1987). "Building High Performing Engineering Project Teams", IEEE Transactions on Engineering Management, EM-34,130-137.

Tables and Figures

Table 1 The triggering events of construction dispute identified by Cheung and Yiu (2006) Table 2 Variables to describe contract governance

Table 3 The Research Plan

Table 4 Factor Structure Matrix for VARIMAX rotated factor solution of negotiating behaviors

Table 5 Factor Structure Matrix for VARIMAX rotated factor solution of Contract Governance

Table 6 Mean Scores and Standard Deviations for the Four Factor Groups of Contract Governance

Table 7 Results of Pearson correlation

Figure 1 A research framework for contract governance and negotiating behaviors

Figure 2 Profiles of respondents (a) by working experience and (b) by professions

Figure 3 Forms of uontract used in the negotiation case 
Table 1 The triggering events of construction dispute identified by Cheung and Yiu (2006)

\begin{tabular}{|c|c|c|}
\hline Non-performance & Payment & Time \\
\hline $\begin{array}{l}\text { I. Inadequate site and/or soil } \\
\text { investigation report }\end{array}$ & $\begin{array}{l}\text { 1. Client fails to pay for } \\
\text { variations claims }\end{array}$ & $\begin{array}{l}\text { 1. Late instructions from } \\
\text { Architect or Engineer }\end{array}$ \\
\hline $\begin{array}{l}\text { 2. Late giving of possession } \\
\text { from Client }\end{array}$ & $\begin{array}{l}\text { 2. Argument on the } \\
\text { measurement and valuation } \\
\text { of contracted work }\end{array}$ & $\begin{array}{l}\text { 2. Consequences on opening } \\
\text { for inspection }\end{array}$ \\
\hline $\begin{array}{l}\text { 3. Client takes over the site } \\
\text { and denies access to Main } \\
\text { Contractor }\end{array}$ & $\begin{array}{l}\text { 3. Delays interim payment } \\
\text { from Client }\end{array}$ & \begin{tabular}{|l|} 
3. \\
$\begin{array}{l}\text { Argument on the time } \\
\text { extension costs claimed by } \\
\text { Main Contractor }\end{array}$ \\
\end{tabular} \\
\hline $\begin{array}{l}\text { 4. Main Contractor denies } \\
\text { assess of the site for the } \\
\text { sub-contractor }\end{array}$ & $\begin{array}{l}\text { 4. Non-payment to } \\
\text { sub-contractor by Main } \\
\text { Contractor } \\
\end{array}$ & $\begin{array}{l}\text { 4. Delay works due to utility } \\
\text { services organization }\end{array}$ \\
\hline $\begin{array}{l}\text { 5. Main Contractor fails to } \\
\text { proceed in a competent } \\
\text { manner }\end{array}$ & $\begin{array}{l}\text { 5. Argument on the } \\
\text { prolongations costs claimed } \\
\text { by Main Contractor }\end{array}$ & $\begin{array}{|ll|}\text { 5. } & \begin{array}{l}\text { Sub-contractor works } \\
\text { delayed due to Main } \\
\text { Contractor }\end{array} \\
\end{array}$ \\
\hline $\begin{array}{l}\text { 6. Architect/Engineer } \\
\text { dissatisfies the work } \\
\text { progress of Main } \\
\text { Contractor }\end{array}$ & $\begin{array}{l}\text { 6. Prolongations costs claimed } \\
\text { by sub-contractor }\end{array}$ & \\
\hline $\begin{array}{l}\text { 7. Main Contractor ceases } \\
\text { work on the site }\end{array}$ & $\begin{array}{l}\text { 7. Late release of retention } \\
\text { monies to Main Contractor }\end{array}$ & \\
\hline $\begin{array}{l}\text { 8. Sub-contractor ceases work } \\
\text { on the site }\end{array}$ & $\begin{array}{l}\text { 8. The assessment of liquidated } \\
\text { and ascertained damages } \\
\text { against Main Contractor }\end{array}$ & \\
\hline $\begin{array}{l}\text { 9. Changes of scope due to } \\
\text { extra work }\end{array}$ & $\begin{array}{l}\text { 9. Argument on acceleration } \\
\text { costs }\end{array}$ & \\
\hline $\begin{array}{l}\text { 10. Errors/substantial changes } \\
\text { in Bills of Quantities }\end{array}$ & & \\
\hline
\end{tabular}


Table 2 Variables to Describe Contract Governance

\begin{tabular}{|l|l|}
\hline \multicolumn{2}{|l|}{ Contract Governance } \\
\hline Item & Descriptions \\
\hline 1. & The procedures for the issuance of Architect's Instructions are very complex. \\
\hline 2. & The procedures for confirmation of verbal instructions by the contractor are complicated. \\
\hline 3. & The time requirements for serving of notices are stringent. \\
\hline 4. & Written notice is a condition precedent for monetary claims. \\
\hline 5. & Written notice is a condition precedent for Extension of Time claims. \\
\hline 6. & The obligation of proof for monetary claim is the sole responsibility of the Contractor. \\
\hline 7. & The obligation of proof for Extension of Time claim is the sole responsibility of the Contractor. \\
\hline 8. & The procedures for obtaining Certificate of Practical Completion are very tedious. \\
\hline 9. & The requirements for obtaining Certificate of Practical Completion are not well defined. \\
\hline 10. & The amount of Liquidated Damages per day is not reasonable. \\
\hline 11. & $\begin{array}{l}\text { There is no time requirement on the contract administrator to respond to claim submissions by the } \\
\text { contractor. }\end{array}$ \\
\hline 12. & The standard of specification is difficult to achieve. \\
\hline & \multicolumn{2}{l}{} \\
\hline
\end{tabular}

${ }^{\text {a }}$ Contract Governance were rated on a scale from 1 (not significant) to 7 (most significant). 


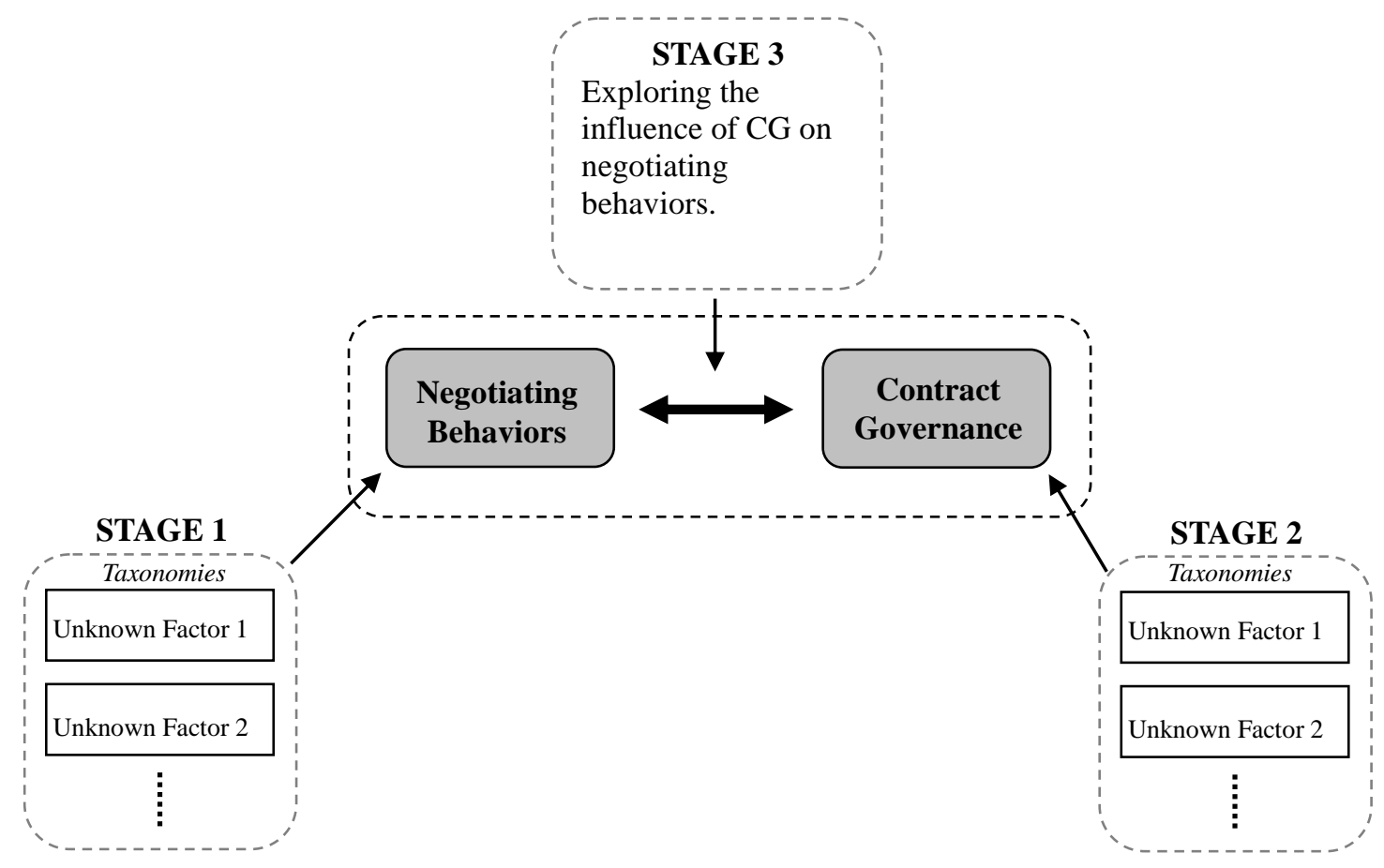

Figure $1 \mathrm{~A}$ research framework for contract governance and negotiating behaviors 
Table 3 The Research Plan

\begin{tabular}{|c|c|c|c|}
\hline Stages of Work & Research Tasks & $\begin{array}{l}\text { Approach \& } \\
\text { Methodology }\end{array}$ & Deliverables \\
\hline $\begin{array}{l}\text { Stages One and } \\
\text { Two: } \\
\text { Development of } \\
\text { Taxonomies }\end{array}$ & $\begin{array}{l}\text { - These stages of work seek to } \\
\text { answer the following three } \\
\text { questions: } \\
\text { 1. What are the typical behaviors in } \\
\text { construction dispute negotiation? } \\
\text { (Stage One) } \\
\text { 2. What constitutes contract } \\
\text { governance? (Stage Two) } \\
\text { * Development of taxonomies for } \\
\text { negotiating behaviors and contract } \\
\text { governance. }\end{array}$ & $\begin{array}{l}\text { - Literature review } \\
\text { - Questionnaire Survey } \\
\text { - Apply Principal } \\
\text { Component Factor } \\
\text { Analyses (PCFA). }\end{array}$ & $\begin{array}{l}\text { - Taxonomies of } \\
\text { negotiating behaviors } \\
\text { and contract } \\
\text { governance }\end{array}$ \\
\hline $\begin{array}{l}\text { Stage Three: } \\
\text { Exploring the } \\
\text { influence of } \\
\text { contract } \\
\text { governance on } \\
\text { negotiating } \\
\text { behaviors }\end{array}$ & $\begin{array}{l}\text { Based on the taxonomies, } \\
\text { exploring the influence of } \\
\text { contract governance on } \\
\text { negotiation behaviors. }\end{array}$ & - Pearson's Correlation & $\begin{array}{l}\text { - Describe the strength } \\
\text { and direction } \\
\text { (positive or negative) } \\
\text { of the relationships } \\
\text { between negotiating } \\
\text { behaviours and } \\
\text { contract governance. }\end{array}$ \\
\hline
\end{tabular}

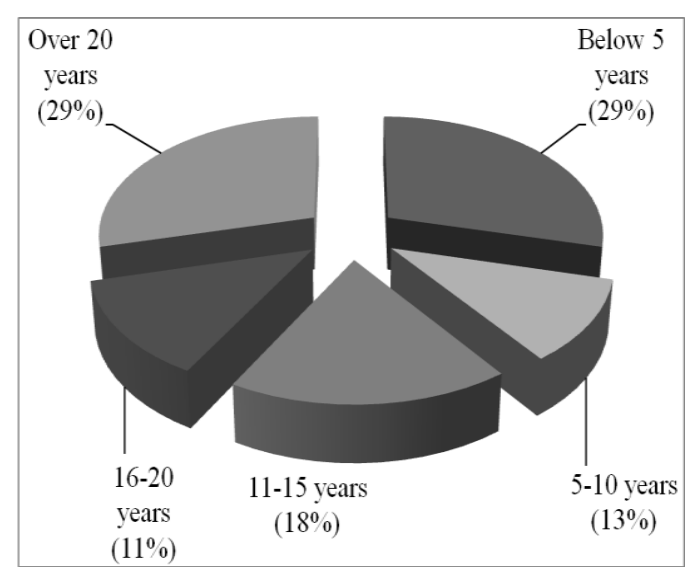

(a)

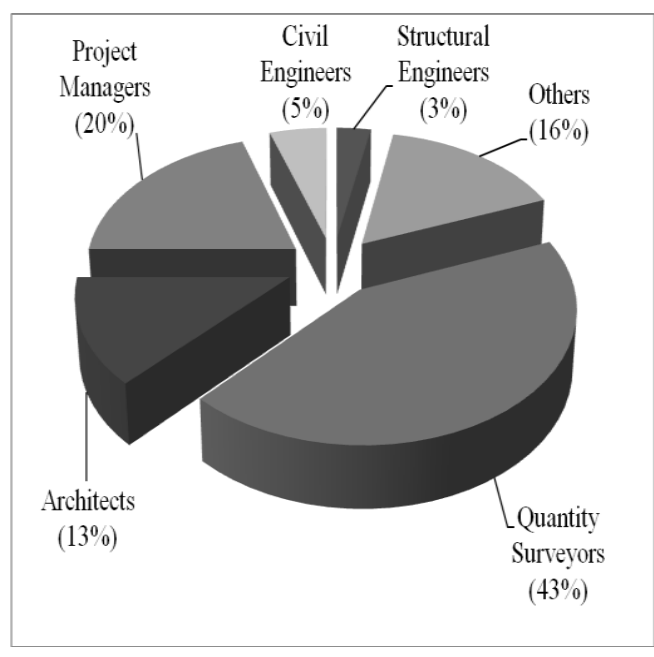

(b)

Figure 2 Profiles of the respondents (a) by working experience and (b) by professions 


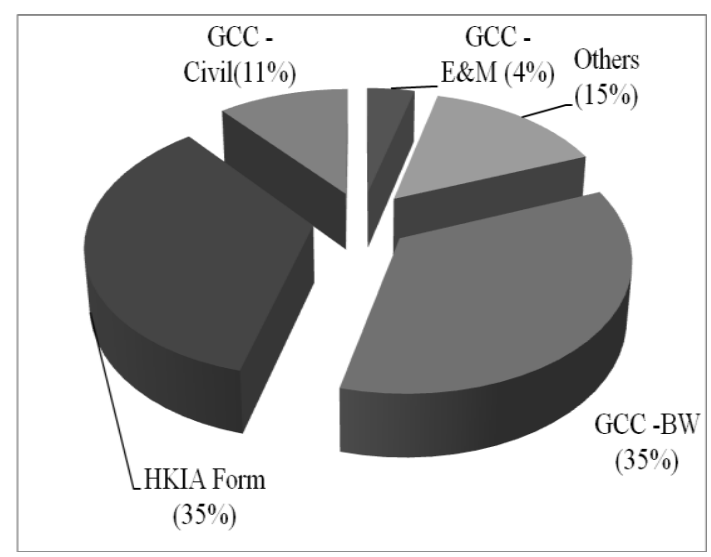

Figure 3 Forms of Contract Used in the Negotiated Case 
Table 4 Factor Structure Matrix for VARIMAX rotated factor solution of negotiating behaviors

\begin{tabular}{|c|c|c|c|c|c|}
\hline \multirow{2}{*}{ Item No. and Content } & \multicolumn{5}{|c|}{ Factors } \\
\hline & 1 & 2 & 3 & 4 & 5 \\
\hline \multicolumn{6}{|l|}{ Factor 1: Integrating } \\
\hline $\begin{array}{l}\text { I try to integrate my ideas with the other party to come up with a } \\
\text { decision jointly. }\end{array}$ & .783 & -.003 & .056 & .085 & .134 \\
\hline $\begin{array}{l}\text { I incline to bring all concerns out in the open so that the issues can } \\
\text { be resolved in the best possible way. }\end{array}$ & .725 & .056 & -.091 & -.003 & .061 \\
\hline $\begin{array}{l}\text { I incline to negotiate with the other party so that a compromise can } \\
\text { be reached. }\end{array}$ & .693 & .235 & .127 & .000 & -.058 \\
\hline $\begin{array}{l}\text { I incline to work with the other party to find solutions to a problem } \\
\text { which satisfy our expectations. }\end{array}$ & .625 & .262 & .110 & -.156 & .089 \\
\hline $\begin{array}{l}\text { I incline to collaborate with the other party to come up with } \\
\text { decisions acceptable to us. }\end{array}$ & .597 & .001 & -.308 & .090 & .342 \\
\hline $\begin{array}{l}\text { I try to work with the other party for a proper understanding of a } \\
\text { problem. }\end{array}$ & .595 & -.084 & -.127 & .096 & -.091 \\
\hline I try to use "give and take" so that a compromise can be reached. & .546 & .057 & .253 & .299 & -.077 \\
\hline $\begin{array}{l}\text { I tend to exchange accurate information with the other party so that } \\
\text { we can solve the problem together. }\end{array}$ & .530 & -.349 & -.243 & -.020 & .165 \\
\hline \multicolumn{6}{|l|}{ Factor 2: Dominating } \\
\hline I tend to use my expertise to make a decision in my favor. & .076 & .822 & .048 & .127 & .129 \\
\hline $\begin{array}{l}\text { I sometimes attempt to use my power to win a competitive } \\
\text { situation. }\end{array}$ & .049 & .798 & .061 & .093 & .148 \\
\hline I try to use my authority to make a decision in my favor. & -.155 & .736 & .207 & .162 & .187 \\
\hline I incline to use my influence to get my ideas accepted. & .162 & .705 & .232 & -.229 & .161 \\
\hline \multicolumn{6}{|l|}{ Factor 3: Avoiding } \\
\hline I try to avoid unpleasant exchanges with the other party. & .040 & -.144 & .800 & .317 & .005 \\
\hline $\begin{array}{l}\text { I incline to keep my disagreements with the other party to myself } \\
\text { to avoid hard feelings. }\end{array}$ & -.063 & .198 & .775 & .037 & .143 \\
\hline $\begin{array}{l}\text { I usually try to avoid open discussion of my differences with the } \\
\text { other party. }\end{array}$ & -.116 & .249 & .654 & -.005 & .190 \\
\hline \multicolumn{6}{|l|}{ Factor 4: Obliging } \\
\hline I am more likely to give in to the wishes of the other party. & -.130 & -.101 & .042 & .815 & .129 \\
\hline I usually try to accommodate the wishes of the other party. & .293 & .303 & -.043 & .640 & -.039 \\
\hline I usually try to allow concessions to the other party. & .063 & .004 & .274 & .548 & .035 \\
\hline \multicolumn{6}{|l|}{ Factor 5: Compromising } \\
\hline I generally try to satisfy the needs of the other party. & -.019 & .280 & .017 & .119 & .761 \\
\hline $\begin{array}{l}\text { I attempt to avoid being "put on the spot" and try to keep my } \\
\text { conflict with the other party to myself. }\end{array}$ & .197 & -.101 & .295 & -.092 & .643 \\
\hline I try to satisfy the expectations of the other party. & .187 & .350 & .033 & .391 & .519 \\
\hline$\%$ of Variance & 14.849 & 13.040 & 10.464 & 9.076 & 8.840 \\
\hline \multicolumn{6}{|l|}{ Kaiser-Meyer-Olkin Measure of Sampling Adequacy: 0.650} \\
\hline & & & & & \\
\hline
\end{tabular}


Table 5 Factor Structure Matrix for VARIMAX rotated factor solution of Contract Governance

\begin{tabular}{|c|c|c|c|c|}
\hline \multirow{2}{*}{ Item No. and Content } & \multicolumn{4}{|c|}{ Factors } \\
\hline & 1 & 2 & 3 & 4 \\
\hline \multicolumn{5}{|l|}{ Factor I: Procedural Requirement } \\
\hline $\begin{array}{l}\text { The procedures for confirmation of verbal instructions by the contractor are } \\
\text { complicated. }\end{array}$ & .827 & .077 & -.077 & -.044 \\
\hline $\begin{array}{l}\text { The procedures for the issuance of Architect's Instructions are very } \\
\text { complex. }\end{array}$ & .769 & .023 & .006 & .003 \\
\hline The time requirements for serving of notices are stringent. & .677 & -.222 & .045 & .491 \\
\hline The standard of specification is difficult to achieve. & .583 & .280 & .279 & -.050 \\
\hline $\begin{array}{l}\text { The procedures for obtaining Certificate of Practical Completion are very } \\
\text { tedious. }\end{array}$ & .520 & .219 & .519 & .141 \\
\hline \multicolumn{5}{|l|}{ Factor II: Burden of Proof } \\
\hline $\begin{array}{l}\text { The obligation/ of proof for monetary claim is the sole responsibility of the } \\
\text { Contractor. }\end{array}$ & -.023 & .883 & .028 & .241 \\
\hline $\begin{array}{l}\text { The obligation of proof for Extension of Time claim is the sole responsibility } \\
\text { of the Contractor. }\end{array}$ & .232 & .865 & -.018 & .211 \\
\hline \multicolumn{5}{|l|}{ Factor III: Ambiguous Provisions } \\
\hline $\begin{array}{l}\text { The requirements of obtaining Certificate of Practical Completion is not well } \\
\text { defined. }\end{array}$ & .127 & -.251 & .834 & -.057 \\
\hline $\begin{array}{l}\text { There is no time requirement on the contract administrator to respond to } \\
\text { claim submissions by the contractor. }\end{array}$ & -.221 & .176 & 668 & .061 \\
\hline The amount of Liquidated Damages per day is not reasonable. & .369 & .004 & .571 & -.033 \\
\hline \multicolumn{5}{|l|}{ Factor IV: Condition Precedent } \\
\hline Written notice is a condition precedent for monetary claims. & -.024 & .243 & .151 & .860 \\
\hline Written notice is a condition precedent for Extension of Time claims. & .032 & .237 & -.134 & .807 \\
\hline$\%$ of Variance & 21.672 & 15.990 & 15.475 & 14.728 \\
\hline \multicolumn{5}{|l|}{ Kaiser-Meyer-Olkin Measure of Sampling Adequacy: 0.566} \\
\hline Bartlett's Test of Sphericity - Approx. Chi-Square: 337.523; df.: 66; Sig.:.000 & & & & \\
\hline
\end{tabular}


Table 6 Mean Scores and Standard Deviations for the Four Factor Groups of Contract Governance

\begin{tabular}{|l|c|c|}
\hline Taxonomies of Contract Governance & Mean score* & Standard Deviation \\
\hline Factor 1: Procedural Requirement & 4.21 & 1.01 \\
\hline Factor 2: Burden of Proof & 5.22 & 1.30 \\
\hline Factor 3: Ambiguous Provisions & 4.02 & 1.12 \\
\hline Factor 4: Condition Precedent & 5.34 & 1.23 \\
\hline
\end{tabular}

*The contract governance was rated in Likert scale of 1 (not significant) to 7 (most significant) 
Table 7 Results of Pearson Correlation

\begin{tabular}{|c|c|c|c|c|c|}
\hline \multirow{2}{*}{\multicolumn{2}{|c|}{$\begin{array}{l}\text { Factor Scales of Negotiating } \\
\text { Behaviors }\end{array}$}} & \multicolumn{4}{|c|}{ Factor Scales of Contract Governance } \\
\hline & & $\begin{array}{l}\text { Procedural } \\
\text { Requirement }\end{array}$ & $\begin{array}{l}\text { Burden of } \\
\text { Proof }\end{array}$ & $\begin{array}{l}\text { Ambiguous } \\
\text { Provisions }\end{array}$ & $\begin{array}{l}\text { Condition } \\
\text { Precedent }\end{array}$ \\
\hline $\begin{array}{l}\text { NB1: } \\
\text { Integrating }\end{array}$ & $\begin{array}{l}\text { Pearson Correlation } \\
\text { Sig. (2-tailed) }\end{array}$ & $\begin{array}{l}-.039 \\
.731\end{array}$ & $\begin{array}{c}.317 * * \\
.004\end{array}$ & $\begin{array}{c}-.108 \\
.338\end{array}$ & $\begin{array}{l}.412 * * \\
.000\end{array}$ \\
\hline $\begin{array}{l}\text { NB2: } \\
\text { Dominating }\end{array}$ & $\begin{array}{l}\text { Pearson Correlation } \\
\text { Sig. (2-tailed) }\end{array}$ & $\begin{array}{l}.257 * \\
.021\end{array}$ & $\begin{array}{l}.258 * \\
.021\end{array}$ & $\begin{array}{l}.229 * \\
.041\end{array}$ & $\begin{array}{c}-.028 \\
.807\end{array}$ \\
\hline $\begin{array}{l}\text { NB3: } \\
\text { Avoiding }\end{array}$ & $\begin{array}{l}\text { Pearson Correlation } \\
\text { Sig. (2-tailed) }\end{array}$ & $\begin{array}{l}.300 * * \\
.007\end{array}$ & $\begin{array}{l}.037 \\
.747\end{array}$ & $\begin{array}{l}.490 * * \\
.000\end{array}$ & $\begin{array}{l}-.045 \\
.691\end{array}$ \\
\hline $\begin{array}{l}\text { NB4: } \\
\text { Obliging }\end{array}$ & $\begin{array}{l}\text { Pearson Correlation } \\
\text { Sig. (2-tailed) }\end{array}$ & $\begin{array}{l}.326 * * \\
.003\end{array}$ & $\begin{array}{l}-.082 \\
.468\end{array}$ & $\begin{array}{l}.270 * \\
.015\end{array}$ & $\begin{array}{l}.229 * \\
.041\end{array}$ \\
\hline $\begin{array}{l}\text { NB5: } \\
\text { Compromising }\end{array}$ & $\begin{array}{l}\text { Pearson Correlation } \\
\text { Sig. (2-tailed) }\end{array}$ & $\begin{array}{l}.383 * * \\
.000\end{array}$ & $\begin{array}{l}.014 \\
.899\end{array}$ & $\begin{array}{l}.189 \\
.092\end{array}$ & $\begin{array}{l}.056 \\
.622\end{array}$ \\
\hline
\end{tabular}

*Correlation is significant at the .05 level (2-tailed)

**Correlation is significant at the .01 level (2-tailed) 
Exploring the influence of contract governance on construction dispute negotiation

Cheung, SO

2008-10

http://hdl.handle.net/10179/16596

22/04/2023 - Downloaded from MASSEY RESEARCH ONLINE 